\title{
Social functioning of a child with Asperger's syndrome in early childhood education in rural areas. Case study
}

\author{
Krzysztof Zajdel ${ }^{1}$ \\ Małgorzata Kabat ${ }^{2}$
}

\begin{abstract}
This article deals with an important issue, namely the integration of people with intellectual disabilities into the group, or rather communication in this integration. In addition to scientific knowledge about this topic, I have described here three cases of students with Asperger's syndrome who attended a public school. The inability of the classroom educators to integrate Marianne, Patrycja and Jakub with their colleagues translated into their functioning in this team. Despite the parents' willingness to help, their messages to the classroom educators - this did not translate into integration as systematic work. There were only occasional cases when a teacher got involved in some activity, but this was definitely not enough to be successful.
\end{abstract}

\section{Keywords}

Asperger's syndrome, younger classes in the countryside, case studies, adaptation in the environment.

\section{Introduction}

A child's development is always a diverse and fluid process, and parents are not always able to see: what is normal and what is not for their child. Most often they compare their offspring to other peers and assess their development on this basis. Any deviations they put on the notch of gender difference or other factors.

The process of socialisation is an important moment when the family environment is still important for the child, but the search for acceptance among peers begins. We cannot function without possible social interactions, pushing someone away, isolating them, stigmatising them negatively - they always have specific consequences. When a child clearly differs from his or her peers by some external feature, e.g. in appearance, even a rather trivial one such as hair colour, freckles, having glasses, can meet with cut-outs, remarks, bad attitude of the group. The same can happen when a child is mentally different from his or her peers, or has a condition that will cause „otherness”, interfere with mutual communication in the team. Adults, teachers, educators play an important role in such situations, as the earliest attempts to „mark” someone else may cause bullying if they are not noticed and pacified in time.

A pupil „different” at school, e.g. autistic pupil, or with Asperger's syndrome is a challenge for the institution, as well as for the classroom team taking care of it, where there is communication within the group, this communication may interfere with the integration process as well as strengthen it.

\section{Description of sickness behaviour}

The name of Asperger's syndrome (ZA) was popularized by Lora Wing in (Kozdroń 2015, p. 10). but this disease has been known for a long time. The leading researcher who dealt with autism was Hans Asperger, who in 1944 published his book „Autistic Psychopathy of Childhood”, describing the type of a disturbed child, where he used the term „autistic psychosis”. He was very fascinated by this disorder, so he devoted

1 Dr Krzysztof Zajdel, University of Zielona Góra, aleja Wojska Polskiego 69, 65-762 Zielona Góra

2 Prof. Małgorzata Kabat, UAM Poznan, ORCID: 0000-0001-6323-8225 
a long period of his life to it. This disorder does not have a strictly defined definition, which is used by everyone, each usually refers to the characteristics of autism. Asparger thought it was: „a disorder that belongs to the group of holistic developmental disorders or otherwise the spectrum of autism." (Komender, Jagielska, Bryńska 2009, p. 51). The same term was also used by Leo Kanner to describe similar symptoms as in autistic children. However, Kanner's work was more interesting because it contained classic features of a quiet, absent child (Attwood 2005, p. 14-15). According to Ulta Frith: „a person with Asperger's syndrome suffers from a particular form of autism, which does not seem very rare" (Frith 2005, p. 8-12). The author also believes that in order to become more familiar with this disorder and why it is considered a variant of autism, one should delve deeper into the overall picture of this disease. As Frith stresses, subsequent research has separated Autism and Asperger's syndrome, specifying that: „everyone assumes that people with Asperger's syndrome belong to the autistic spectrum. They all believe that a common feature of Asperger's syndrome and autism in general is a particular type of communication failure and social „ineptitude”. Nevertheless, they perceive people with Asperger's syndrome as being different from other autistic people, communicating better thanks to a more developed language and having a better chance of successful adaptation (Frith 2005, p. 12-20). Attwood says that: „Currently, this syndrome is considered a subgroup of autism spectrum disorders and has its own diagnostic criteria. There is also evidence that this disorder is much more common than classical autism and can be diagnosed in children who have never been considered autistic before (Attwood 2005, p.16).

On the other hand, children with autism are characterized by abnormal participation of in alternating social interactions. These disorders, however, differ in individual children. They appear early in development, even before the age of 6 months (1993,p. 42-45). As the child develops, further symptoms appear - no indication of objects of interest to the child, disturbances in eye contact, lack of interest in people, ignoring people in the environment, including peers. They are not able to play with children of their own age, they cannot understand the rules of play, they are more interested in adults, older or younger children. Some children do not keep a distance from strangers, may use them as objects, touch or jerk. Children are not interested in getting to know people, animals, but only objects in their surroundings. Lack of possibility to communicate verbally and nonverbally with the environment significantly impairs social development of children. In many situations that are simple for their peers, children with autism are unable to cope, showing extraordinary abilities including the already mentioned excellent memory, mathematical skills, as well as musical, artistic and spatial skills (Pisula 2005, p. 29-32).

Therapy of children with Asperger's syndrome and autism are mainly activities leading to desired changes in the patient's functioning i.e. psychotherapy, sociotherapy, re-education, compensation, correction. Thanks to these actions the patient functions better in social life, copes with his problems, thinking, behavioral or emotional disorders. The therapy requires wide support in various aspects and its aim is to support the child's development, leveling and compensating deficits characteristic for autism, i.e. disturbances in social functioning, communication and behaviour (Błeszyński 2005, p. 156-158). Of course, each case of diagnosed ZA and autism differs in individual children, their social interaction and communication with the environment are also different.

\section{Class team integration}

A school class is a group of students who interact with each other, hold different positions, share a common system of values and standards governing their behaviour, etc. It is characterized by a dynamic system of group phenomena and processes. Initially, it forms only a formally organized social group including students representing a similar level of mental and physical development. The informal current of internal classroom life is usually the result of mutual and spontaneous interactions between students. It emerges from the moment when they make their first interpersonal contacts with each other. With time, it becomes much deeper and begins to exert more influence on them than the formal control exercised over it from outside, e.g. in the form of recommendations or instructions from teachers (Łobocki 2005, p. 80-85).

In the overall educational impact on the individual, the peer group plays an important role in the socialisation process. It satisfies those social needs which educators, representing the adult generation, 
are not able to satisfy: the need to belong to a team whose members perform equal, although diverse social roles on the basis of „equal with equal”, the need to establish social contacts and exchange views and opinions without the participation of adults. Thanks to strong motivation, participation in a peer group - depending on the role played there - strengthens the self-esteem and the sense of social usefulness of an individual. The mechanism of socialisation by belonging to a peer group also consists in the fact that the person joining the group is very much interested in the recognition of its members. This recognition must be earned, as must the sympathy of colleagues by behaving in accordance with the standards and sanctions in force in the group. This is a different situation from that of the family, where a child is most often accepted and loved, no matter how much he or she deserves it. The penalties imposed by the group are also more ruthless than those imposed by parents and teachers. The most severe punishment is the rejection of the child by colleagues, isolating it from the group.

For fear of such a sanction, members often behave conformistically, even against their own beliefs (Przetacznik - Gierowska, Włodarski 2004, p. 86-102).

It is worth noting that the position that a student occupies in the general class structure depends on many conditions. These include

- The possibility of exerting or not exerting influence on others, e.g. by performing or not performing a specific function in the classroom;

- the degree to which the student is liked or disliked by his or her classmates;

- ability to make interpersonal contacts (communication) with others or lack thereof;

- Subordination or non-subordination to classroom standards, particularly in the informal classroom;

- high or low intellectual ability, including progress or failure to learn;

- pleasant or unpleasant physical appearance (Janowski 2002, p. 57).

In the classroom - as a social group with an appropriately shaped and constantly developing structure - students are bound by certain group standards. These are norms ,developed' by the students themselves, which constitute an important reference system for them, regulating their behaviour in various situations. These norms are rather rarely verbalised and clearly understood, let alone never generally written down; they are usually not included in any officially prepared register. They represent a shared view among the classroom's students of how they should behave, especially in lessons. They are an exemplary generalisation of how to anticipate such behaviour or an idea of how to behave in the classroom to gain recognition and how not to behave to avoid disapproval.

The school classroom (especially in small towns, e.g. in the countryside) gives many pupils the opportunity to be successful, provides a sense of security and satisfaction, and fosters positive selfesteem and positive attitudes towards other people. However, there are individuals among children for whom being among their classmates is a source of unpleasant experiences, uncertainty, conviction of their lesser value, which in effect leads to the formation of hostile attitudes towards themselves and their surroundings. From this fact, there is a need to know the factors that determine whether a child is attractive to colleagues or not, which of them - under the influence of the teacher's conscious influence can contribute to increasing the child's popularity among colleagues and thus to avoiding the consequences of a long-term lack of acceptance. The most important thing is to give every child a chance to create the conditions for showing their values, development and self-fulfilment. All this creates an opportunity to meet the need for new experiences, self-fulfilment, own development as a unique unit (Pawłowska 2000, p. 28-29). This is important in the process of integration.

\section{Seeing "I" in integration with another}

The formation of the self-image takes place primarily under the influence of the social environment and specific life experiences. Self image is not a permanent image, it changes with the child's development under the influence of various factors.

Analysing the functions of upbringing in personality development, we will consider two issues: the role of upbringing influences in the formation of this aspect of the cognitive network, which with age leads to an increasingly profound self-knowledge and cognition of oneself; these properties are connected with the development of the "self” structure, which provides the individual with a sense of identity despite the changes that take place in it throughout life. 
The second issue is the relationship: the self-world, which is linked to the human being's position in the social environment. The place of the structure of the „I” in the whole personality is specific in that it includes both cognitive components - it talks about the image of oneself, the notion of one's own „I”, self-knowledge, self-cognition or self-awareness, as well as emotional, valuing and functional components - it includes self-esteem, self-control, self-esteem, sense of identity (Przetacznik -Gierowska, Włodarski 2004, p. 1-4-120).

All components listed here are interconnected and interdependent. The ideas and concepts that an individual has about himself or herself, i.e. about his or her appearance, abilities, possibilities, undertaking and performing various activities and tasks. The way in which an individual judges himself or herself, whether he or she feels great or small self-esteem, whether he or she is relatively satisfied and accepts himself or whether the image of himself or herself gives rise to unpleasant experiences and sensations.

We most often talk about the social integration of children with disabilities when we want to show the difficulties that fate presents to them. This is in line with the common tendency to see disabled children as deeply unhappy children whose lives have been disrupted, broken up, wasted once and for all. The difficulty that stands in the way of analyzing the psychological and social situation of children with disabilities is the dynamics of the phenomenon. These situations are not something permanent, unchangeable, which could be unambiguously characterized. They change with the process of adaptation of both the child and his or her environment to the disability. They are different at the moment of experiencing a disability, different when the child has already adapted to it. So we can only discuss them within the framework of the transformations that take place in the process of adaptation, giving rise to qualitatively different stages in it.

The development of a disability interferes with the whole process of children's adaptation to life. The level of adaptation they have already achieved is disrupted. In order to rebuild it, to achieve the balance in relations with the world, it is necessary to adapt to the disability, which can be long lasting, during which the child learns about his or her own disability, gets used to it, learns to overcome the difficulties caused. Information about one's own disability stops arousing very strong, long-lasting emotions and activating defensive mechanisms. The child accepts it in a relatively neutral way (Kowalewski 1991, p. 55-58).

And what about self-confidence in your ability to achieve independence in everyday life, selfconfidence? The importance of this factor is particularly emphasized by authors who are supporters of the social model of disability. According to them, it should first of all point out the capabilities and competences of people with disabilities. This will facilitate the creation of a positive image of the disabled person, allow them to believe in themselves and, as a result, increase their motivation to integrate into society. However, when being a disabled person makes it impossible to meet the most important needs, the individual begins to feel a clear dissonance between expectations and reality (Komorska 2000, p. 20-21). In order to reduce the unpleasant sensations associated with it, the disabled person is forced to change their previous values. Objectives that are achievable in the new situation should become important, but impossible to achieve - invalid.

\section{The functioning of peer groups in a classroom team}

To talk about the specificity of the functioning and roles of peer groups - it should be stressed that in the process of socialisation, a peer group plays an extremely important role. It is the educational group that satisfies those needs of the individual that cannot be satisfied by parents or educators. This is because an individual who participates in a peer group has the opportunity to improve their self-esteem and usefulness. This fact depends on the role played in the peer group - the higher the level of popularity in the group, the higher the individual's self-esteem. The fact that an individual depends on the acceptance and recognition of other members of the group also has a positive effect on the socialization of the individual in the peer group. However, one has to earn recognition and sympathy. The individual therefore follows the standards of the group and recognises the sanctions imposed by the group. In some cases, natural peer groups are formed among target groups of young people, of which all or some of the participants in the target group become members. It may also happen that several peer groups are formed within one target group. 
In associations, on the other hand, we often have to deal with the formation of secondary peer ties, because the formation of associations is conditioned by specific relationships (e.g. religious or ideological) and often results from emotional needs. The task of each educator and teacher is to become familiar with how peer relationships (both primary and target groups) affect an individual, because during his or her teaching and educational work he or she meets them almost every Day (Pilch, Lepalczyk 1995, p. 15).

An important role in this system is played by the so-called group standards, which include three determinants. The first is the assessment of the importance of different types of behaviour from the point of view of group interests. The second and third determinant of group norms are expectations concerning the desired behaviour of group members and the group's reactions to its members' behaviours, which take the form of positive sanctions (rewards) in the case of desired behaviours, and negative sanctions (penalties) in the case of undesirable behaviours that are contrary to the interests of the group (Stefańczyk 2008, p. 48-53). A school class is a secondary group, formed in a formal way for mainly didactic purposes. However, when it is transformed into an informal group, it can have a huge impact on an individual. Informal groups are a variety of primary groups. The individual belongs to them on the basis of common interests, and the members contact each other frequently and personally on a voluntary basis.

\section{Children's attitudes to otherness}

How are attitudes in children developing? Each attitude is shaped to a greater or lesser extent by the influence of one's own experience, the experience of society, as well as social values and patterns. And yes: „individual experience gained mainly through influencing specific objects” (Nowak1973, p. 321-322). In the course of experience, beliefs concerning a specific object are formed. It is easier to change a child's attitude towards something or someone, because a few years old does not yet have his own opinion. The transmission of information is a method often used to change other people's attitudes. The author gives many examples of how to pass on information in order to have a positive impact on changing attitudes. According to the author, this requires not only a moral principle, but also the principle of effective persuasion (Nowak 1973, p. 322-325).

In such a situation it is not difficult to feel lonely, without the possibility of communicating with peers who have a certain attitude towards „otherness”. Loneliness is a special experience of people who are rejected, with whom no one from the class team wants to contact or communicate. Such children may have different reactions to this state. One of them is self-aggression. Self-aggression often takes only the form of radical understatement of self-esteem, verbal humiliation of oneself. Often, however, self-aggression pushes children to self-harm. It can be inflicting wounds on oneself with a knife or razor blade, burning, etc. The pain inflicted by a child on itself is an emanation of low self-esteem felt by the child, a radical attempt to punish itself for its „imperfection”. It is also a form of communication with the environment, a drastic form of crying for help.

Social, emotional and intellectual development can be shaped by the environment, so early stimulation and therapy are very important. „Early intervention, reaching the first moment from the birth of a child with disabilities, not only changes the quality of life of the whole family, but opens up perspectives that need to be filled with content until old age" (Kaczmarek 2010, p. 11-12). It is similar in the school period when we choose a school that will prepare the disabled person for independence and active life. It will give him a sense of security and further development among friends. However, with time, as the child grows older, a new task appears, more important and definitely more difficult, namely to design their future. „Adulthood, or adolescence itself, very often brings with it loneliness, lack of attractive or at least decent forms of leisure activities, thoughtful rehabilitation, lack of specialists or support groups. Parents and family again stay alone with their adult child. Again, as in the face of birth, the painful question returns: what next? (Kaczmarek 2010, p. 85). It is not an easy decision to choose a school to which parents will give up their disabled child. It can be a school with integration classes, co-operative classes or a special school. It all depends on the child's own predisposition.

Every person with intellectual disabilities (including people with a disability or autism) is different, has their own abilities and needs, predispositions and limitations, as well as interests and strengths and weaknesses. It is therefore difficult for teachers and therapists to meet their needs, so their 
education looks different depending on the stage of education. It looks best in classes I-III, then it is much more difficult, which often involves the need to change the school to one in which an autistic child may feel happy and safe, and education will take place at the level of his or her abilities (special classes, special schools).

Prejudice to a person with intellectual disabilities is caused by automatic generalization and negative cultural attitudes. To change this, the approach of the social environment to intellectual disability needs to be changed. "The source of the process of supporting young people and adults with disabilities is the contemporary tendency to classify mental disability in the context of social systems of the theory of delay in development, based on the criterion of the intensity of support a person needs in the following areas: intellectual functioning and adaptability, emotional functioning, physical health and contact with the environment" (Kaczmarek 2010, p. 86-87). It is not at all easy to change the prejudices and conducts towards children from the ZA and autistic individuals as well as members of e.g. a class team.

\section{Research}

For the purposes of this article, I analyzed three individual cases of children with Asperger's syndrome diagnosed in public schools, in grades III. The analysis was based on conversations with tutors (in grades I-III the tutor spends most of his time with children, except for learning religion, languages, sometimes sports activities), observing children, talking to parents and pupils. The schools were located in rural areas on the outskirts of Wrocław. They were typically agricultural municipalities, without industry. The size of schools was about 300, 350 and over 425 pupils. Each of these schools had commuting (transporting) students from neighboring smaller towns.

\section{Sociometric study}

A student's position in the classroom is determined by his or her level of acceptance in the classroom, and the level of acceptance of the student has a significant impact on his or her overall social development. The purpose of my research was to determine the degree of intensity of emotional connections that become established when students interact with each other in the school community. As a result, the results of my research allowed me to:

- to know the degree of mutual sympathy;

- to identify the most liked students;

- to identify the disliked, rejected students in the classroom.

I studied students with the classical sociometric technique Moreno- is one of the techniques representing a high level of excellence. As a sociometric technique, it can be successfully used to study students' attitudes towards each other in order to learn about stacks in the classroom. I asked one question in each class team: who of the students in the classroom would you invite to your birthday party, name 3 student names. After analyzing the class teams, the results are as follows.

Table 1. Percentage of peer elections

\begin{tabular}{|l|l|l|}
\hline $\begin{array}{l}\text { Number of children } \\
\text { (percentage score) } \\
\text { Facility 1 (19 pupils) }\end{array}$ & $\begin{array}{l}\text { Number of children } \\
\text { (percentage score) } \\
\text { Facility 2 (23 pupils) }\end{array}$ & $\begin{array}{l}\text { Number of children } \\
\text { (percentage score) } \\
\text { Facility 3 (17 pupils) }\end{array}$ \\
\hline $3(16 \%)$ & $4(13 \%)$ & $5(15 \%)$ \\
\hline $9(47 \%)$ & $16(75 \%)$ & $6(47 \%)$ \\
\hline $7(37 \%)$ & $3(12 \%)$ & $6(38 \%)$ \\
\hline
\end{tabular}

Source: Survey and own study.

My research shows that people from the ZA were not indicated as the most frequently chosen people to invite to a birthday party. They were in the group of less frequently chosen people (35\%) and nonelected people (65\%). Teachers must help children to eliminate such behaviours by educating the rest of the students that all people with disabilities have the same rights, only fewer opportunities to be like 
the rest of the class team. Teachers are aware of this, but do not always do so. The same applies to the parents of students. In my free conversation with them, during their visits to the institution or when picking up their children from school, they were generally not interested in other students, they were very focused on their children. Their attitude could be described as a claim. They did not very much accept the fact that a teacher has to devote more time to a pupil from the ZA, they saw in the actions of teachers the harm to their children (less time for the realization of classes), and they also emphasized the fact that children from the ZA are „too absorbing” for teachers.

I will now describe some of the observations I have made.

\section{The case of Patricia}

She was a very late child because her mother gave birth to her in her fifty-second birthday, her siblings (two sisters) when Patrycja started going to school were already married, they had their own children. The parents were educated people, doctors in a recognized medical institution. They knew what kind of illness Patrycja was suffering from, so their whole effort was focused on rehabilitation from an early age. It consisted in providing the best possible development, support, rehabilitation and acceptance to the child. Thus all kinds of arttherapeutic activities, hippotherapy, learning to play instruments, animals at home, etc., were focused on the child's development, support, rehabilitation, acceptance.

\section{The case of Marianne}

She was a very much awaited child. Her mother, before she gave birth to Marianne, had long been cured of infertility. The birth was very difficult. It's an only child, no siblings. At the first symptoms of ZA, the child's father left the house, the parents helped the mother to raise the child, devoting themselves very much to it and supporting both the child and the mother. The child was rehabilitated, went to specialist camps with his mother (among others, for stays in Mrzeżyno) (The official website of rehabilitation camps in Mrzeżyno) and was enrolled in many therapeutic activities.

\section{The case of James}

First child, second child (girl) healthy. The parents treated the child's illness as a challenge, went abroad with him, applied innovative therapies, wanted to organize a meeting with the parents of the other students in the facility to introduce their son's problem, but there was no interest. The mother did not work for many years, devoting herself to her son's rehabilitation. The family of the child's father, after Jakub was born, moved away from his grandson, only recognize the granddaughter, who is fit and healthy.

\section{The functioning of children in a class team,}

Patrycja had behaviors that were not accepted by the class team, which quite often pushed her aside from class life. They did not want to sit on the same bench with her, play, or have fun alone when she was already involved in it was to ridicule her, to press on with the roles that made the class happy. Marianne was very anxious for the acceptance of the classroom team, so she provoked various situations in class life to get this acceptance (e.g. loud singing in class, squeaking) and behaved as the group expected. Communication also consisted in the fact that the more laughter there was on the part of the group the more she felt appreciated, she did activities inadequate to normal behaviour at that age, e.g. she was greasing herself with ketchup, she repeated the vulgarities her peers from the class, when asked, she used these vulgarities in relation to the teacher.

When asked by a classmate: who she would like to become, Jacob replied that she was „a goat with boobs," which caused so much cheerfulness that the pupils from the older classes were called to listen. Then he was so happy that so many people reacted to him, patting on his back, saying by name, „accept.

Kids have generally had better days, worse days. In those worse days, they were like behind glass, inaccessible, they did not react to any external stimuli, they were in their own world, often without a smile, without contact with others. All attempts at communication were then fruitless. Patrycja could, for example, play with a pen for hours, repeat some monosyllables, look at one point. This was her message to her surroundings: today there is no communication with me, I am in my own world and it is good here. Of course, the class did not accept such behaviour, because they wanted to have a „class laugh” 
at every call and provoked her. Her behaviour then in these „bad days” could finish with manifestations of aggression, biting, screaming, etc.

The tutor in Patricia's class tried to tame it, but these were only attempts which, after the failures in this field, accepted a certain course of action to pacify Patricia. The messages to this child were usually negative or indifferent. This teacher also did not react to the classroom children's hoaxes against Patricia, pretending not to see them. Communication in this class integration was clumsy. In other schools, it was similar. Only in Jacob's class, the tutor tried different ways of working with this student. He created duty, help circles, assistance teams (e.g. for playing at a break). This had positive effects, perhaps because he was a very experienced teacher with many years of experience in his profession.

Generally speaking, no one teaches potential early school teachers how to deal with such situations. They are unprepared, but they do not usually look for support, because they think that it is not „Worthwhile” to invest in e.g. training, because they will not have such a case in the next class team. The degree of reaction, communication with students and this particular child really depends on the sensitivity of the particular teacher and educator.

\section{Communication of the child with the ZA with teachers and Barents}

I was interested in the observed cases of these children, because it seemed to me that the mass media outlets have systemic solutions in working with such children, discussing problems, looking for solutions, communicating with each other, improving their skills. During the observation I had the opportunity to get to know the good days and the bad days of the respondents, I met my parents, we talked a lot. I discovered that e.g. when Patrycja had a good day and wanted to make me happy, she was able to give the results very quickly e.g. multiply the four-digit numbers in her memory. When I told the teacher about it and "showed" that it was happening, the teacher was very surprised, even though he had been teaching the child for almost three years. As a non-teacher in this class, I discovered it.

In the „good” days Patrycja was able to stick nicely in plasticine or modeling, she had interesting and interesting characters, which was completely absent from the drawings. She was very interesting and inquisitive, sometimes I even noticed a certain perspicacity in her deductions when we talked. Of course, there were also fixations at some point that could last a week, sometimes even longer, if the class provoked her to do so, for example, once, after watching an animated film about cows, she associated herself with this animal, painted cows in notebooks, signed on sheets of paper: Marianne Cow. This made the class happy, but no one was communicating with their parents, why is this happening? If he did, it would already be known that the reason for this is this animated film, and without this information the very object of merriment - the cow - remained.

How was communication with James? He asked me, for example, who is pop? I answered that he was a priest in the Orthodox religion. By the way, I informed him that pop may have a wife, which is not in the Roman Catholic religion. I confirmed what made him extremely happy. You could have a normal conversation and so I did, on many subjects, this communication was interesting for me and for him. Why did he not communicate in this way with the educator?

By the way, I tried to improve communication within the class group and Patricia. When solving the tasks, taking advantage of Patricia's „good day”, I used her as a „calculator” to suggest results without counting on an abacus, which she did very eagerly, while enjoying the class's applause for her abilities. In the "good days” she was also able to play pieces on the piano, a part without notes, a part with notes. Other children did not manage to do so, which increased her „value” in the group. I explained to the class that each one of us is specific, that once we act in some way, sometimes differently, but this is no reason to stigmatize him or hurt him with words. Everyone is unique and everyone should be respected.

The parents of all the examined children were at the teacher's disposal, they asked that they would come to the school if necessary, talk at a meeting with the parents of the students from the class to which their children went, give lectures, etc. Patricia's parents offered a meeting for the whole class in the garden of their home, an integration picnic. He never took advantage of this offer.

\section{Summary}

The extent to which a disabled child communicates with his or her peers is very important for that child. It promotes integration, getting to know each other, filling in the gaps and taming „otherness”. It 
takes a long time to reach „normality”, although there is still much to be done in this area. I remember about 40 years ago I saw a mother turning her son's head, who was walking with her by the hand, because on the other side of the street a child with a significant mental handicap was riding in a special pram. She was probably afraid that her healthy child would „get infected” from this disabled person. Many years have passed since then, a lot has changed, but still the mutual communication between the disabled and able-bodied does not always develop as we would like it to. Of course, students of the broadly understood special pedagogy know about it, but usually, if they take up a job, they work only with such children, i.e. the disabled, some of them go to integration classes. There you can promote mutual communication, understanding and acceptance. In public school classes there are sometimes children with some kind of disability, but their functioning sometimes has a disturbed communication with their peers. Mutual relationships always depend on the attitude of teachers and educators and „until” depends only on them.

There are many factors that influence the formation of a self-image. In the case of people with disabilities, it is important that they perceive their developmental deficits by themselves and their environment. A positive attitude of people who are authorities and highlighting the strengths of people with disabilities will certainly influence the formation of high self-esteem.

\section{Bibliography:}

[1] Attwood T. (2005), Zespół Aspergera. Kompletny przewodnik, Gdańsk, Wydawnictwo Harmonia.

[2] Błeszyński J. (2005), Rodzina jako środowisko osób z autyzmem, Aspekt wychowawczo-terapeutyczny, Toruń, Wydawnictwo Uniwersytetu Mikołaja Kopernika.

[3] Frith U (2005)., Autyzm i Zespół Aspergera, Warszawa, Wydawnictwo lekarskie PZWL.

[4] Jaklewicz H. (1993), Autyzm wczesnodziecięcy - diagnoza, przebieg, leczenie, Sopot, Gdańskie Wydawnictwo Psychologiczne.

[5] Janowski A. (2002), Pedagogika praktyczna: zarys problematyki- zdrowy rozsądek- wyniki badań, Warszawa, Fraszka Edukacyjna.

[6] Kaczmarek B. (2010), Trudna dorosłość osób z zespołem, Kraków, Impuls.

[7] Komorska M. (2000), Sytuacja dzieci i młodzieży niepełnosprawnej w społeczeństwie polskim, Lublin, Wydawnioctwo UMCS.

[8] Komender J., Jagielska G., Bryńska A. (2009), Autyzm i Zespół Aspergera, Warszawa, Wydawnictwo Lekarskie PZWL.

[9] Kowalewski L.(1991), Psychologiczna i społeczna sytuacja dzieci niepełnosprawnych, [w:] Dziecko niepełnosprawne w rodzinie, (red.) I. Obuchowska, Warzawa, WSiP.

[10] Kozdroń A.(2015), Zespół Aspergera. Zrozumieć, aby pomóc, Warszawa, Difin.

[11] Łobocki M. (2005), Teoria wychowania w zarysie, Kraków, Impuls.

[12] Nowak S. (1973), Teorie postaw, Warszawa, PWN.

[13] Pawłowska H. (2000), Rola klasy w stymulowaniu rozwoju dziecka w młodszym wieku szkolnym, Życie Szkoły 2000 nr. 1/2000.

[14] Pisula E. (2005), Małe dziecko z autyzmem, Sopot, Gdańskie Wydawnictwo Psychologiczne.

[16] Pilch T., Lepalczyk I. (1995), (red.), Pedagogika społeczna: człowiek w zmieniającym się świecie, Warszawa, Wydawnictwo Żak.

[17] Przetacznik - Gierowska M., Z. Włodarski Z. (2004), Psychologia wychowawcza, Warszawa, PWN, Warszawa.

[18] Stefańczyk A. (2008), Psychologia wywierania wpływu i psychomanipulacji. Jak skutecznie wpływać na innych i bronić się przed negatywnym wpływem z ich strony, Wydawnictwo Gliwice, Złote Myśli.

\section{Web pages}

Turnusy rehabilitacyjne dla osób z ZA:

www.turnusy.rehabilitacyjne.pl/[dostęp marzec 2020] 